Економічні науки: збірник наукових праць Луцького національного технічного університету. Серія "Регіональна економіка". Випуск 18 (71). Редкол.: відп. ред. д.е.н., професор Л.Л. Ковальська. Луцьк: ІВВ Луцького НТУ, 2021. 278 с.

Yana Suchukova. Publishing House of the University of Technology, Katowice. 1239 p. Pp. 1084-1089.

5. Nezdoiminov S., Bedradina G. (2018) Scientific and methodological bases of assessing the quality of tourist services. Bulletin of socio-economic research. collection. Science. Works, Odessa National Economic University. Odessa. Issue 67 (3). Pp. 63-72.

6. Official site of the State Agency for Tourism Development of Ukraine. Access mode URL: https://www.tourism.gov.ua/about-dart

7. Official site of the Department of Tourism and Promotion of the city of Lutsk City Council. Access mode URL: https://www.lutskrada.gov.ua/departments/upravlinnia-turyzmu-ta-promotsii-mista

8. Papp V. Organizational mechanism of quality management of services at tourist enterprises. Economy and society. Issue 15. 2018. Access mode URL: http://economyandsociety.in.ua/journal-15/22-stati-15/1873-papp-v-v-boshota-n-v

9. Prospects for tourism development in Ukraine and the world: management, technology, models. Collect. Monograph (2019) According to the scientific edition L. Matviychuk. Lutsk: ED Lutsk NTU. 324 p.

10. Quality management systems. Basic provisions and glossary of terms: DSTU ISO 9000: 2007 (ISO 9000: 2005), IDT. Valid from 2008-01-01. K: Derzhspozhyvstandart Ukrainy, 2008. 29 p. National standard of Ukraine.

11. Yukhnovska Y. (2019) Research of the potential of the tourism industry of competitive regions of Ukraine. State and regions. Series: Economics and Entrepreneurship. № 5 (110). S. 65-70.

DOI: https://doi.org/10.36910/2707-6296-2021-18(71)-13

УДК 339.138:330.341.1

Морохова В.О., к.е.н., професор

Бойко О.В., к.е.н., доцент

Лорві І.Ф., к.е.н., доцент

Луцький національний технічний університет

\title{
МАРКЕТИНГ ІННОВАЦІЙ ЯК КОМПЛЕКСНИЙ ІНСТРУМЕНТ ДОСЯГНЕННЯ СТРАТЕГІЧНИХ ЦІЛЕЙ ПІДПРИЄМСТВА В УМОВАХ КОНКУРЕНТНОГО СЕРЕДОВИЩА
}

У статті розглянуто питання маркетингового забезпечення інноваційної діяльності підприємств на засадах побудови ефективної системи маркетингу 
Економічні науки: збірник наукових праць Луцького національного технічного університету. Серія "Регіональна економіка". Випуск 18 (71). Редкол.: відп. ред. д.е.н., професор Л.Л. Ковальська. Луиьк: ІВВ Луиького НТУ, 2021. 278 с.

інновацій. Систематизовано дослідження вітчизняних науковців стосовно особливостей маркетингу інновацій як комплексного інструменту досягнення стратегічних цілей підприємства. Визначено комплекс завдань маркетингу інновацій, які об'єднано в три групи: стратегічні, тактичні та оперативні. Доведено практичну значимість маркетингу інновацій в обслуговуванні процесу розробки та реалізації інновацій.

Ключові слова: маркетинг, інновації, маркетинг інновацій, інноваційна діяльність, потреби споживачів, прогнозування попиту, конкурентні переваги, маркетингова інноваційна стратегія.

\section{Morokhova V., Boyko O., Lorvi I. \\ MARKETING OF INNOVATIONS AS A COMPREHENSIVE TOOL FOR ACHIEVING STRATEGIC GOALS OF THE ENTERPRISE IN A COMPETITIVE ENVIRONMENT}

The article considers the issues of marketing support of innovative activity of enterprises on the basis of building an effective system of innovation marketing. The study of the problems of innovation management of enterprises has shown that their innovative development is impossible without effective marketing support. The goal of creating innovations can be achieved only when innovations will be in demand among certain groups of consumers and will fully meet their needs. Innovation marketing facilitates the timely identification and control of factors that determine the effectiveness of innovation in the market.

The research of domestic scientists on the peculiarities of innovation marketing as a complex tool for achieving the strategic goals of the enterprise is systematized. The use of marketing innovations to identify market opportunities and minimize market threats is significantly relevant in an unstable market with fierce competition. Innovation marketing is aimed at the commercialization of innovations, the creation of which should be preceded by marketing research of consumer needs, market conditions and the definition of the market segment to meet the needs of which innovation will be directed. Innovation marketing ensures the production and sale of innovative competitive products that fully meet current demand. The approaches of scientists to the interpretation of marketing innovations are revealed: as a concept of market activity of the enterprise; as a process of analysis of market opportunities; as a means of active influence on consumers; as a function of innovation management; as a means of orienting enterprises to innovative development.

A set of tasks for innovation marketing has been identified, which are grouped into three groups: strategic, tactical and operational. Strategic objectives can be implemented by conducting marketing research of the innovation market, analysis of real consumption and potential demand for innovation, study of the level of competition and development of innovative models of enterprise behavior in the market. Marketing innovation strategy is one way to ensure sustainable competitive 
Економічні науки: збірник наукових праць Луцького національного технічного університету. Серія "Регіональна економіка". Випуск 18 (71). Редкол.: відп. ред. д.е.н., професор Л.Л. Ковальська. Луцьк: ІВВ Луцького НТУ, 2021. 278 с.

advantage. Tactical tasks include the development of specific product innovations (portfolio of product innovations) within the selected options for innovation development and assessment of their commercial prospects, taking into account the possibility of multivariate market developments. The operational objectives of innovation marketing are related to the implementation of the chosen innovation strategy with the help of modern marketing technologies by initiating constant changes in needs, updating the range, achieving new levels of satisfaction of needs, using new forms of communication and sales.

The practical significance of innovation marketing in servicing the process of innovation development and implementation is proved. Innovation marketing not only helps to meet consumer needs, but is also an effective tool for identifying them and provides a link between the innovation process and consumption. Further research should be aimed at improving the system of marketing support for innovative development of enterprises on the basis of active implementation of marketing innovations.

Key words: marketing, innovations, marketing of innovations, innovative activity, needs of consumers, demand forecasting, competitive advantages, marketing innovation strategy.

\section{Морохова В.А., Бойко О.В., Лорви И.Ф. МАРКЕТИНГ ИННОВАЦИЙ КАК КОМПЛЕКСНЫЙ ИНСТРУМЕНТ ДОСТИЖЕНИЯ СТРАТЕГИЧЕСКИХ ЦЕЛЕЙ ПРЕДПРИЯТИЯ В УСЛОВИЯХ КОНКУРЕНТНОЙ СРЕДЫ}

В статье рассмотрены вопросы маркетингового обеспечения инновационной деятельности предприятий на основе построения эффективной системы маркетинга инноваций. Систематизированы исследования отечественных ученых по особенностям маркетинга инноваций как комплексного инструмента достижения стратегических целей предприятия. Определено комплекс задач маркетинга инноваций, которые объединены в три группы: стратегические, тактические и оперативные. Доказана практическая значимость маркетинга инноваций в обслуживании процесса разработки и реализации инноваций.

Ключевые слова: маркетинг, инновации, маркетинг инноваций, инновационная деятельность, потребности потребителей, прогнозирование спроса, конкурентные преимущества, маркетинговая инновационная стратегия.

Постановка проблеми у загальному вигляді і її зв'язок 3 важливими науковими та практичними завданнями. Дослідження проблем управління інноваційною діяльністю 
Економічні науки: збірник наукових праць Луцького національного технічного університету. Серія "Регіональна економіка". Випуск 18 (71). Редкол.: відп. ред. д.е.н., професор Л.Л. Ковальська. Луиьк: ІВВ Луиького НТУ, 2021. 278 с.

підприємств показало, що їх інноваційний розвиток неможливий без ефективної маркетингової підтримки. Досягти мети створення інновацій можна лише тоді, коли інновації будуть користуватись попитом у певних груп споживачів та повною мірою задовольнятимуть їх потреби. Зазначене обумовлює необхідність використання маркетингу інновацій для своєчасного виявлення i контролювання факторів, що визначають ефективність інновацій на ринку.

Аналіз останніх досліджень, у яких започатковано вирішення проблеми. Питання маркетингового забезпечення інноваційної діяльності підприємств знайшли своє відображення в роботах таких зарубіжних i українських науковців, як: I. Ансофф, Ф. Котлер, М. Портер, Й. Шумпетер, Л.Л. Антонюк, Л.В. Балабанова, С.М. Ілляшенко, Ю.В. Каракай, С.В. Ковальчук, Т.С. Максимова, А.О. Старостіна I.Л. Решетнікова, П.Г. Перерва, Н.I. Чухрай та ін. Проте прикладні аспекти застосування інструментарію маркетингу інновацій в інноваційній діяльності вітчизняних підприємств залишаються актуальними і такими, що потребують подальших досліджень.

Метою статті $\epsilon$ визначення особливостей маркетингу інновацій як комплексного інструменту досягнення стратегічних цілей підприємства в умовах конкурентного середовища.

Виклад основного матеріалу дослідження 3 повним обгрунтуванням отриманих наукових результатів. Переважна більшість дослідників відзначає визначальний вплив маркетингу на формування i зміст інноваційної стратегії підприємств. Застосування маркетингу інновацій для виявлення ринкових можливостей i мінімізації ринкових загроз значно актуалізується в умовах нестабільного ринку із жорсткою конкуренцією.

На думку C.M. Ілляшенка, «маркетинг інновацій передбачає реалізацію традиційних функцій та завдань маркетингу в процесі створення та поширення інновацій задля найкращого задоволення потреб i запитів споживачів i виробників» [1, с. 36]. 
Економічні науки: збірник наукових праць Луцького національного технічного університету. Серія "Регіональна економіка". Випуск 18 (71). Редкол.: відп. ред. д.е.н., професор Л.Л. Ковальська. Луиьк: ІВВ Луиького НТУ, 2021. 278 с.

Вербицька Г.Л. під маркетингом інновацій пропонує розуміти діяльність, що спрямована на комерціалізацію інновацій, створенню яких повинні передувати маркетингові дослідження потреб споживачів, кон'юнктури ринку та визначення сегменту ринку, на задоволення потреб якого будуть спрямовані інновації. Автор основною метою маркетингу інновацій формулює наступну: «створення такої продукції, яка б не просто задовольнила, але й перевершила очікування споживачів» [2, с. 38]. Тобто інновація буде успішною за умов володіння атрибутами, які відсутні у конкурентів.

На практичних аспектах маркетингу інновацій наголошують автори публікації [3]. На їх думку, маркетинг інновацій забезпечує виробництво і збут інноваційної конкурентоспроможної продукції, яка в повному обсязі задовольняє актуальний попит. Науковці визначають маркетинг інновацій як «діяльність, що спрямована на пошук нових сфер бізнесу, розробку абсолютно нових видів продукції та впровадження у виробництво інновацій для вже існуючих товарів» [3, с. 188].

Каракай Ю.В., наголошуючи на зростанні ролі інновацій у процесі соціально-економічного розвитку, розглядає маркетинг інновацій як сферу маркетингової діяльності організації «щодо розробки та просування товарів, послуг, проектів, які мають нові значущі властивості (стійкі конкурентні переваги)» [4, c. 20].

Окремі дослідники розглядають маркетинг інновацій 3 точки зору системного підходу як «комплексну систему підприємства, спрямовану на аналіз i управління нововведеннями на основі маркетингової інформації i за допомогою маркетингових засобів» [5, с.83].

В цілому сукупність поглядів науковців на маркетинг інновацій можна представити наступним чином: 1) як концепція ринкової діяльності підприємства; 2) як процес аналізу ринкових можливостей; 3) як засіб активного впливу на споживачів; 4) як функція інноваційного менеджменту; 5) як засіб орієнтації підприємств на інноваційний розвиток. 
Економічні науки: збірник наукових праць Луцького національного технічного університету. Серія "Регіональна економіка". Випуск 18 (71). Редкол.: відп. ред. д.е.н., професор Л.Л. Ковальська. Луиьк: ІВВ Луиького НТУ, 2021. 278 с.

Маркетинг інновацій виконує комплекс завдань, які можна об'єднати в три наступні групи [2]:

- стратегічні (спрямовані на формування стратегічного бачення інноваційного розвитку підприємства та розробку маркетингової інноваційної стратегіi);

- тактичні (спрямовані на формування портфеля товарних інновацій та оцінку їх комерційних перспектив);

- оперативні (спрямовані на розробку комплексу засобів маркетингу для інноваційних товарів).

Стратегічні завдання можуть бути реалізовані шляхом проведення маркетингових досліджень ринку інновацій, аналізу реального споживання і потенційного попиту на інновацію, дослідження рівня конкуренції та розробки інноваційних моделей поведінки підприємства на ринку. Стратегічний інноваційний маркетинг визначається, насамперед, сегментуванням ринку та позиціонуванням товару, а ключовим його аспектом виступає дослідження і прогнозування попиту на новий товар, що базується на ретельному вивченні сприйняття споживачем інновації. Маркетингові дослідження надають необхідну інформацію про споживачів, яка виступає основою для пошуку найбільш ефективних шляхів задоволення потенційних потреб ринку та розробки стратегії поведінки підприємства на ринку. Маркетингова інноваційна стратегія $є$ одним із способів забезпечення стійких конкурентних переваг. Однак, як зазначено в [3], при розробці такої стратегії фахівці 3 маркетингу повинні володіти грунтовними знаннями i навичками стосовно створення цінності для споживачів за рахунок надання їм нових товарів, розробки та використання інноваційних методів просування i збуту продукції, комерціалізації інновацій, тощо.

Тактичні завдання передбачають розробку конкретних товарних інновацій (портфелю товарних інновацій) у межах обраних варіантів інноваційного розвитку та проведення оцінки ïх комерційних перспектив 3 урахуванням можливості багатоваріантного розвитку подій на ринку. 
Економічні науки: збірник наукових праць Луцького національного технічного університету. Серія "Регіональна економіка". Випуск 18 (71). Редкол.: відп. ред. д.е.н., професор Л.Л. Ковальська. Луиьк: ІВВ Луиького НТУ, 2021. 278 с.

Оперативні завдання маркетингу інновацій пов'язані 3 реалізацією обраної інноваційної стратегії за допомогою сучасних маркетингових технологій шляхом ініціювання постійних змін потреб, оновлення асортименту, досягнення нових рівнів задоволення потреб, використання нових форм комунікацій та продажу.

Таким чином, практичне значення маркетингу інновацій полягає в обслуговуванні процесів розробки та реалізації інновацій, формування інноваційної стратегії підприємства, а також у виявленні факторів, від яких залежить конкурентоспроможність нових товарів та підприємства в цілому.

Висновки. Маркетингове забезпечення інноваційної діяльності підприємств передбачає здійснення відповідних маркетингових заходів: 1) проведення маркетингових досліджень ринку, що дає можливість виявити незадоволені потреби споживачів та генерувати ідеї інновації; 2) підбір відповідних елементів комплексу маркетингу з метою адаптації інновації до потреб ринку; 3) формування ринкового попиту на нововведення. Маркетинг інновацій не просто сприяє задоволенню споживчих потреб, а й є ефективним інструментом їх виявлення та забезпечує зв'язок інноваційного процесу та споживання. Подальші дослідження повинні бути спрямовані на вдосконалення системи маркетингового забезпечення інноваційного розвитку підприємств на засадах активного впровадження маркетингових інновацій.

\section{Список бібліографічного опису}

1. Ілляшенко С.М. Маркетинг. Менеджмент. Інновації: монографія. Суми: ТОВ «Друкарський дім «Папірус», 2010.623 с.

2. Вербицька Г.Л. Особливості маркетингової підтримки інновацій вітчизняних промислових підприємств в умовах міжнародних економічних відносин. Вісник Начіонального університету «Львівська політехніка». Логістика. 2016. № 846. С. 36-41.

3. Курбацька Л.М., Кадирус I.М. Впровадження маркетингових інновацій у діяльність промислових підприємств. Економіка та держава. 2020. № 4. С. 187-190.

4. Каракай Ю.В. Маркетинг інноваційних товарів : монографія. Київ : KHEУ, 2005. 226 c. 
Економічні науки: збірник наукових праць Луцького національного технічного університету. Серія "Регіональна економіка". Випуск 18 (71). Редкол.: відп. ред. д.е.н., професор Л.Л. Ковальська. Луцьк: ІВВ Луцького НТУ, 2021. 278 с.

5. Мостова А.Д. Теоретичні аспекти інноваційного маркетингу та маркетингу інновацій. Європейський вектор економічного розвитку. 2017. № 1. C. 79-86.

\section{References}

1. Ilyashenko S.M. (2010) Marketynh. Menedzhment. Innovatsii: monohrafiia [Marketing. Management. Innovations: monograph]. Sumy: Papyrus Printing House LLC, 2010. 623 p. (in Ukrainian)

2. Verbytska G.L. Osoblyvosti marketynhovoi pidtrymky innovatsii vitchyznianykh promyslovykh pidpryiemstv $\mathrm{v}$ umovakh mizhnarodnykh ekonomichnykh vidnosyn [Peculiarities of marketing support of innovations of domestic industrial enterprises in the conditions of international economic relations]. Bulletin of the National University «Lviv Polytechnic». Logistics. 2016. № 846. pp. 36-41. (in Ukrainian)

3. Kurbatskaya L.M., Kadyrus I.M. Vprovadzhennia marketynhovykh innovatsii u diialnist promyslovykh pidpryiemstv [Implementation of marketing innovations in the activities of industrial enterprises]. Economy and state. 2020. № 4. pp. 187-190. (in Ukrainian)

4. Karakay Y.V. Marketynh innovatsiinykh tovariv : monohrafiia [Marketing of innovative goods: monograph]. Kyiv: KNEU, 2005. 226 p. (in Ukrainian)

5. Mostova A.D. Teoretychni aspekty innovatsiinoho marketynhu ta marketynhu innovatsii [Theoretical aspects of innovation marketing and innovation marketing]. European vector of economic development. 2017. № 1. pp. 79-86. (in Ukrainian)

DOI: https://doi.org/10.36910/2707-6296-2021-18(71)-14 